\title{
Post-'Brexit' Financial Governance: Which Dispute Settlement Framework should be utilised?
}

\section{A}

Introduction

In the field of financial governance (the mechanisms that support the regulation and supervision of the financial markets) a number of UK/EU legal disputes may emerge post'Brexit'. This article examines the UK's current track record at the Court of Justice of the European Union ('CJEU'), and discusses some likely future challenges. In light of this, it considers which institutional frameworks should be used for resolving them. The article assesses the strengths and weaknesses of three potential models and provides an original cross-model evaluation. It also discusses the associated design challenges that EU and UK negotiators may encounter in the attempt to devise a post-Brexit dispute settlement system. This timely contribution to the ongoing Brexit discussions addresses topical legal and regulatory issues in the UK/EU post-Brexit policy debate, especially the questions surrounding the important area of financial governance and dispute resolution.

The article's analysis is qualified by the following observation; it proceeds on the basis that rational and functional interests and concerns should win out in the Brexit dispute settlement negotiations. Be that as it may, it is acknowledged that Brexit is not a rational endeavour and that the withdrawal negotiations witnessed to date do not necessarily point to such interests offering a reliable guide to the future Brexit arrangements.

At the time of writing, both the date for the UK's departure from the EU, and the future nature of the UK/EU relationship remain uncertain. Although the Draft UK/EU Withdrawal Agreement and the Future Political Declaration have been endorsed by the leaders of the EU-27 and the UK's Prime Minister, they have repeatedly failed to make it through the UK Parliamentary process. ${ }^{1}$ Regardless of their final status, however, the Draft Withdrawal Agreement's dispute resolution system merits examination. The provisions amount to a cautious compromise, embracing a quasi-judicial system of arbitration plus the involvement of the CJEU in relation to EU law issues. ${ }^{2}$ The approach in the Draft is not so surprising given the EU's stronger position in the negotiations, although the UK did secure a key concession with the inclusion of the arbitration mechanism.

Over the longer term, however, although the CJEU must remain the ultimate arbiter on EU law within the EU order, as a matter of principle, it may not be the appropriate forum for dispute resolution between the UK and the EU. Rather, a standard feature of many international agreements is the use of an institutional forum that is independent of both jurisdictions and which can offer impartial oversight. Dispute resolution systems can also vary depending on the substance of an agreement in question, as well as the levels of mutual trust and cooperation that exist between the parties. Applying this to the field of UK/EU financial governance, on the one hand a close future partnership may be envisaged, taking account of the long shared history of the UK and the EU in this highly regulated and

\footnotetext{
${ }^{1}$ Draft UK/EU Withdrawal Agreement (as Endorsed by the European Council) 2018; Political Declaration on the Future UK/EU Relationship 2018.

${ }^{2}$ As discussed further below, one of the EU's 'red lines', see e.g. Opinion 1/92 ECLI:EU:C:1992:189.
} 
dynamic area. ${ }^{3}$ At the same time, given the continually evolving nature of financial governance, this may also heighten the probability of future legal challenges. Indeed, this has been clearly evidenced during the UK's time as a Member State when it has challenged the EU's competency in this area on a number of occasions. Taken together, a robust future UK/EU institutional framework could help to monitor both sides complying with the terms of a future agreement as well as offering effective dispute resolution when required. On the other hand, given the unpredictable state of the Brexit situation, the precise level of any future UK/EU collaboration remains a matter of on-going speculation. Yet in the event there is either no agreement (whether with respect to financial governance or more generally), or only a light-touch future association materialises, a dispute settlement system will still be required, although this will be somewhat different in its form.

More generally, there are broader aspects that may also impact upon the eventual design of a future UK/EU dispute resolution mechanism. A full examination of such issues exceeds the scope of the article; nonetheless, such variables should be borne in mind when surveying the potential institutional models as these could also affect the shape of a new dispute settlement system. First, financial governance is only one, albeit a vital, issue in the wider Brexit dispute settlement endeavour. For instance, how the Brexit financial settlement plays out could influence the nature of any post-Brexit system. In brief, the Brexit financial settlement sets out how the UK and EU will settle their outstanding financial commitments to one another and currently forms part of the Draft Withdrawal Agreement. In the event that a so-called 'no deal' scenario materialises, however, it is probable that a combination of political considerations and the level of appetite that emerges for a future UK/EU relationship will then dictate the extent to which financial commitments are settled and vice versa. Particularly in the situation where the UK leaves the Union without making any payment whatsoever, this could have profound consequences on the structure of a future UK/EU arrangement. ${ }^{4}$

Further, the EU guidelines on the framework for future EU/UK relations may also impact upon the design of a new relationship. Particularly given EU concerns that UK businesses could gain unfair competitive advantages post-Brexit (such as via regulatory divergence), the EU guidelines make any future agreement dependent on there being sufficient guarantees for a 'level playing field' for EU and UK businesses, accompanied by adequate dispute settlement mechanisms. The guidelines also note that designing the governance of the future relationship will necessitate taking into account the content and depth of the future relationship as well as the requirements of the autonomy of the EU legal order, including the role of the CJEU. ${ }^{5}$ Again, such guidelines suggest that what may be considered acceptable from the EU's point of view (including with respect to the role of the CJEU) will likely depend on what is appropriate given the depth of the relationship that emerges.

Taken together, these examples illustrate the wider variables within the wider Brexit context that may also influence the final form of a financial governance dispute settlement system.

\footnotetext{
${ }^{3}$ To chart the history, see e.g. E. Ferran, Building an EU Securities Market (Cambridge University Press 2004); for a comprehensive and incisive analysis of this area, see e.g. N. Moloney, EU Securities and Financial Markets Regulation (3rd edn, Oxford University Press, 2014).

${ }^{4}$ House of Commons, Brexit: The Financial Settlement: Briefing Paper No. 8039 (July 2019) 26-30.

${ }^{5}$ European Council, Guidelines for Future EU-UK Relations: 20001/18 (March 2018) articles 12 and 15; House of Commons, Brexit: New Guidelines on the Framework for Future EU-UK Relations: No. 8289 (April 2018), section 9.
} 
Accordingly such elements should be kept in mind in relation to the frameworks under examination.

With this in mind, the overall thesis will be developed as follows: the first substantive section examines the UK's recent legal challenges at the CJEU with respect to financial governance disputes. This section highlights the propensity for disagreements to emerge in this swiftly evolving area. It also paves the way for the following section, which turns to explore the potential for post-Brexit financial governance disagreements to emerge, particularly with respect to the third-country equivalence process, as well as recent EU developments in relation to the oversight of third-country central counterparties (although technical, this sector matters in terms of the financial system as a whole). This section identifies that there are a number of difficulties with the UK bringing such applications to the CJEU but that in principle some types of action could be open to legal review. The article then turns to analyse and evaluate the potential institutional structures that could be engaged for a post-Brexit system: the proposed bilateral Swiss/EU institutional framework; the regional EFTA Court, particularly the possibility of the UK 'docking' at it (in essence, enabling the UK to access the EFTA Court without having to sign up for the full acquis of European Economic Area ('EEA') law); and the international World Trade Organisation ('WTO') resolution system.

The issues in question are legally complex and political delicate and it is challenging to identify solutions that can balance both sides' expectations and 'red lines'. The three institutional models that are evaluated all have their own pluses and minuses, and (as observed above) there are related obstacles that may be encountered in developing a postBrexit system. The bilateral Swiss/EU situation is pertinent to reflect on as some notable similarities have emerged between the UK/EU and the Swiss/EU negotiations. First, Switzerland is neither a EU Member State nor an EEA State. Next, for both the UK and the Swiss, the on-going negotiations are not between equals; it is the pitting of the supranational 'club' of the EU against a non/soon to be non-member. The geographical proximity of both countries to the EU also affects the negotiations: the closer the nonmember, the greater the intensity of the relationship. Indeed, Switzerland has indicated that the EU can be observed connecting the conferral of single market access rights to the political progress of the Swiss institutional negotiations. ${ }^{6}$ The EU is also taking care to treat the UK and Switzerland pari passu; it does not wish to set precedents for one jurisdiction that the other may then claim.

If a close future alliance can emerge then the Swiss/EU draft framework (that is currently applied in the Draft UK/EU Withdrawal Agreement) could be utilised, however, the article suggests that the innovative EFTA docking solution may be preferable, subject to building in the necessary adaptations. The EFTA model is more intricate but it can also offer more leeway, including in relation to respecting the UK's stance on the CJEU. Such a route could include the UK securing a future bespoke agreement with the EU (rather than joining the EEA, the so-called 'Norway option') whilst granting the EFTA institutions a role in dispute resolution. Ideologically, this could have attractions for the UK; EFTA is not a supranational institution and it has a different ethos focused on free trade rather than the pursuit of further political integration. Moreover, the EU has accepted the EFTA Court system, and has in the past offered it as a solution to the Swiss situation, suggesting this may be acceptable to it. At the same time, it could hit the same political roadblocks as the Draft Withdrawal

\footnotetext{
${ }^{6}$ G. Baur, The UK's Ability to Conclude Trade Agreements Post Brexit and Potential Frameworks (Cambridge, Brexit Symposium) (March 2019).
} 
Agreement, given that EFTA generally follows the case law of the CJEU. There also could be jurisdictional complexities with respect to the applicability of the current EFTA model to equivalence disputes, although the mutual respect that has developed over the years between the EFTA Court and CJEU may moderate this to an extent.

If the future negotiations deteriorate, however, then a looser arrangement that draws on the international WTO model may be the only realistic system on which to start designing a future dispute settlement system. The WTO has a well-developed, largely successful quasijudicial system. This could be utilised in the UK/EU's future arrangements, including with respect to financial governance disputes. Although the WTO is not a standard-setter and the question of market access rights to EU would remain dependent (in the first instance) on the EU's third country frameworks, the WTO settlement mechanisms could provide a neutral system for settling future disputes. It could offer important oversight over the equivalence process, including assessing whether the denying or revoking of such decisions on either side is incompatible with WTO standards. ${ }^{7}$

There are limitations to this procedure, including how far the regime can engage in the review of particular EU/UK disputes concerning equivalence, yet the WTO may be open to policing unjustified denials or revocations of access determinations. ${ }^{8}$ Moreover although the WTO's Appellate Body currently faces existential challenges due to the US blocking appointments, a number of functional solutions have been mooted that may ensure it remains operational. Although it remains unclear whether or not such systems will be sufficient, ${ }^{9}$ in principle such mechanisms could be transferable in relation to future UK/EU disputes. ${ }^{10}$ With respect to the domestic political aspects, however, given the Brexit policy on escaping the CJEU's jurisdiction, there may be the need for deft political thinking to avoid the CJEU being replaced in the wider imagination with the WTO's tribunal in Geneva. ${ }^{11}$

The UK's Track Record at the CJEU: EU 3 - UK 1

\section{B EU Financial Governance and the UK}

This section considers the UK's long-standing role as a major influence and check and balance in relation to EU competence with respect to financial governance. It demonstrates that given the dynamic nature of the field of financial governance, challenges to the EU's competence can quickly emerge. Further, in more recent years, as the UK has struggled to maintain its influence in shaping new EU laws directly at the negotiating table, it has instead taken challenges to the CJEU. This section provides the bedrock for the following section,

\footnotetext{
${ }^{7}$ K. Alexander, 'The UK's Third-Country Status Following Brexit' in Brexit and Financial Services: Law and Policy (Hart 2018) 139.

${ }^{8}$ A. Lang, 'The 'Default Option'? The WTO and Cross-Border Financial Services Trade after Brexit' in Brexit and Financial Services: Law and Policy (Hart 2018).

${ }^{9}$ C. Creamer, 'From the WTO's Crown Jewel to Its Crown of Thorns' (2019) 113 American Journal of International Law 51.

${ }^{10}$ See e.g. 'EU and Canada Agree on Interim Alternative to WTO Appeal Court' Financial Times (25 July 2019); W. Reinsch, J Caporal and J Heering, Article 25: An Effective Way to Avert the WTO Crisis? (CSIS) (January 2019). Options include using binding arbitration for appeals instead of the Appellate Body.

${ }^{11}$ G. Messenger, 'Membership of the WTO' in Michael Dougan (ed), The UK after Brexit: Legal and Policy Challenges (Intersentia 2017) 235.
} 
which then highlights the prospect of post-Brexit legal challenges emerging in respect of financial services.

With respect to the field of financial governance, the UK's financial sector is the largest in Europe; it is sometimes described as the EU's investment banker. ${ }^{12}$ As a Member State, the UK has had voting power within the EU institutions, via the widely used qualified majority voting ('QMV') procedure in the Council of the EU (the 'Council'). ${ }^{13}$ Although analyses of voting behaviour show that the Council does not always vote formally, preferring to reach consensus, factors influencing the outcome of QMV decisions may include Presidency preferences, coalition forming, and 'horse trading'. ${ }^{14}$ Especially in the pre-global crisis era, the UK was often an authoritative voice with respect to financial governance, given it had much subject-specific expertise. ${ }^{15}$ Moreover, it could also trade favours with other countries when they did not have a 'dog in the fight' in return for support on their vital interests. ${ }^{16}$ More recently, however, the UK's approach fell from favour following the global crisis. Its influence at the negotiating table waned (and announcing its departure from the Union proved to be a further large nail in its coffin). Taken together, it has become more challenging for the UK to secure blocking coalitions in the Council. For instance, on the bankers' bonus cap (which restricted bonuses to 100 per cent of pay, or 200 per cent with shareholder approval) no other Member State was willing to support the UK's opposition. ${ }^{17}$ Accordingly, in recent years the UK has instead resorted to contesting EU measures at the CJEU. ${ }^{18}$

Starting with its one (limited) victory at the CJEU, this was in relation to the clearing of financial contracts (derivatives). The UK has a well-established euro-derivatives clearing business. This fairly obscure (but also crucial) sector of clearing is the mechanism by which a

\footnotetext{
${ }^{12}$ D. Howarth and L. Quaglia, 'Brexit and the Single European Financial Market' (2017) 55 Journal of Common Market Studies 149, 150; N. Moloney, 'Brexit, the EU and Its Investment Banker: Rethinking 'Equivalence' for the EU Capital Market' (LSE Law, Society and Economy Working Papers 5/2017).
}

${ }^{13}$ A qualified majority is reached if two conditions are met: 55 per cent of Member States vote in favour representing at least 65 per cent of the population. A blocking minority can be ensured with at least four Council members representing more than 35 per cent of the population, see Treaty on the Functioning of the European Union ('TFEU') art 238(3) and Treaty on European Union ('TEU') art 16.

${ }^{14}$ See e.g. T. Börzel, 'Member State Responses to Europeanization' (2002) 40 Journal of Common Market Studies 193.

${ }^{15}$ D. Howarth and L. Quaglia (n 12).

${ }^{16}$ D. Leal-Olivas, 'Brexit Redraws EU Alliances' Politico <https://www.politico.eu/article/brexitredraws-eu-alliances-coalitions-stop-france-and-germany-deeper-integration/> accessed 11 October 2018; N. Moloney, "Bending to Uniformity": EU Financial Regulation with and without the UK' (2017) 40 Fordham International Law Journal 1336, 1357. Studies show that traditionally the UK voted against EU measures more often than other Member States (although even so it rarely voted against proposals), see V. Miller, Voting Behaviour in the EU Council: UK Parliament Research Briefing (2013) $1,13-14$

${ }^{17}$ In particular, the UK argued this legislation was not fit for purpose; the provisions would increase fixed salary components, which would make banks riskier. The UK also maintained it was at the forefront of the global shift in tackling unacceptable pay practices, see A. Barker, 'UK Isolated as EU Backs Bonus Cap' Financial Times (5 March 2013).

${ }^{18}$ N. Moloney, “Bending to Uniformity': EU Financial Regulation with and without the UK' (n 16). 
third party central counterparty ('CCP') acts as a middleman for derivatives agreed between a buyer and seller. ${ }^{19}$ A clearinghouse (such as the London Stock Exchange's LCH) stands between the two parties as a CCP and insulates the rest of the market if there is a default. The City of London is the dominant global location for clearing derivatives trades, including the euro; and it became even more significant following the post-crisis G20 moves to centrally clear over-the-counter contracts. ${ }^{20}$

The location of (what can now be) systemically important clearing facilities has long been contentious (and tensions have been reignited due to Brexit, as will be discussed further below). In this regard, in 2011 the UK challenged the European Central Bank's ('ECB's) location policy on CCPs that clear euro-denominated transactions, arguing that the ECB did not have the competence to impose a location requirement on CCPs.

In 2015 the CJEU annulled the policy in so far as it set a requirement for CCPs involved in clearing euro-denominated transactions to be located in the eurozone. At the same time, this was a limited success by the UK. The CJEU only focused on the UK's first plea, that the ECB did not have the competence to regulate the activity of securities clearing systems and that the ECB's competence was limited to payment systems. The CJEU did not examine the UK's other pleas, including that the policy infringed the Treaty provisions relating to services, capital and establishment. ${ }^{21}$

The three other CJEU challenges were unsuccessful. First, as identified above, the UK was isolated in the negotiations leading to the EU rules capping bankers' bonuses. At the CJEU, its legal challenges included the EU's lack of competence to regulate pay, ${ }^{22}$ but it withdrew its application, in light of the Advocate General's opinion. This opined that all of the UK's arguments should be rejected. ${ }^{23}$

The UK also challenged the 2011 Proposal to introduce a 'Robin Hood' financial transaction $\operatorname{tax}($ 'FTT'), which would generate a new source of income from the financial sector. The proposed tax would have extra-territorial effects, including transactions in non-participating jurisdictions, provided one party was located in a participating Member State, or where the parties were trading financial instruments issued in a participating Member State. ${ }^{24}$ In this

\footnotetext{
19 'What Is London's Euro Clearing Market and Why Is Brussels Worried?' Financial Times (13 June 2017) <https://www.ft.com/content/18dcf566-5025-11e7-bfb8-997009366969> accessed 18 October 2018 .

${ }^{20}$ G20 Leaders' Declaration: Pittsburgh Summit (September 2009); K. Lannoo, The Fight over Clearing Euro Derivatives (ECMI Commentary: No 50/15 March 2018 2018).

${ }^{21}$ Case T-496/11 UK v ECB (Location Policy) ECLI:EU:T:2015:133, paras 78; 110.

${ }^{22}$ HM Treasury, Legal Challenge Launched into New Rules on Bankers' Pay (September 2013).

${ }^{23}$ Case C-507/13 UK v Parliament and Council Opinion of AG, ECLI:EU:C:2014:2394. In light of the Brexit vote, this issue has again been reignited. Mark Carney, the governor of the Bank of England has suggested this is an area that could be recalibrated; with a view not towards a race to the bottom, but to make changes whilst retaining the overall level of resilience, C. Binham, 'Bankers' Bonus Cap Could Be Scrapped after Brexit, Says Carney' Financial Times (29 November 2017).

${ }^{24}$ See e.g. S. Peers, The UK's Failed Challenge to the Financial Transaction Tax: Keep Calm and Wait (April 2014).
} 
instance, the UK suffered an early stage defeat in its attempt to rein in the FTT, although largely on procedural grounds. The CJEU took the view that the UK's arguments were hypothetical components of future legislation; consequently the arguments were premature and speculative..$^{25}$ At the same time, the ruling noted that the UK could make a subsequent challenge for annulment of any final FTT adopted. ${ }^{26}$ In this regard, a leaked legal opinion of the Council's legal service also considered the Proposal exceeded Member States' jurisdiction for taxation under customary international law, infringed the taxing competence of non-participating countries, and was discriminatory. ${ }^{27}$

Finally, the UK challenged the European Securities and Markets Authority's ('ESMA') market intervention powers under the Short Selling Regulation on a range of legal grounds, including whether such competences were compatible with the Meroni constraints on the delegation of powers to unelected agencies, and with respect to the use of the article 114 TFEU legal basis (an argument which the Advocate General supported). In this case, the CJEU dismissed the UK's pleas in their entirety. ${ }^{28}$

Taken together, the UK's victories at the CJEU have been few, and even the one success concerned a relatively niche aspect of its application. Despite the UK's rather poor track record, as the next section considers, a number of possible future challenges in respect of financial services could now emerge due to Brexit, whether during the transition period (if this transpires) and thereafter. Financial governance is a highly dynamic and heavily regulated area, and a number of areas could be ripe for challenge. In this regard, the likelihood and level of complaints may depend not only the questions of substance but also the levels of trust between the jurisdictions. Indeed, given the current, shaky state of the Brexit negotiations, it is unclear whether any firm UK/EU arrangement may emerge. As identified in the introduction, in the situation where there is no agreement, this could also have profound implications on any future relationship as well as (most likely) increasing the chances of future disagreements emerging.

\section{A Future Legal Applications at the CJEU}

\section{B What Challenges Could Emerge?}

This section analyses the prospects for future disagreements in respect of post-Brexit financial governance. With respect to future legal complaints, the general starting point is that there could be implementation disputes. This could involve, for example, one party

\footnotetext{
${ }^{25}$ Case C-209/13 UK v Council ECLI:EU:C:2014:283, para 26.

${ }^{26}$ Ibid para 34.

${ }^{27}$ Council of the EU Opinion of the Legal Service, Interinstitutional File 2013/0045 (CNS) (September 2013). Note that the FTT project continues to be debated by ten participating countries (under the enhanced cooperation procedure (article $20 \mathrm{TEU}$, and arts 326-334(1) TFEU) whereby if Member States fail to achieve an objective within a reasonable period of time, a minority (of at least nine) may proceed. Even if it is adopted, this could be challenged on its merits, however, Commission, Proposal for Implementing Enhanced Cooperation in the Area of Financial Transaction Tax COM(2013) 71 Final (2013); ECOFIN, Press Release 5555/13 (22 January 2013).

${ }^{28}$ Case C-270/12 UK v Council and Parliament ECLI:EU:C:2014:18; see e.g. C. Bergström, 'Shaping the New System for Delegation of Powers to EU Agencies: UK v Parliament and Council' (2015) 52 CMLR 219.
} 
arguing that the other is not appropriately implementing the relevant UK/EU agreement. There could also be challenges with respect to subsequent executive actions (such as the EU making equivalence determination, including the threat or actual revocation of an equivalence assessment). ${ }^{29}$ Moreover, there could be legal challenges in relation to EU legislative action, where this has or could impact negatively on third-country sectors and actors.

This section explores possible legal challenges that may arise in the field of financial governance. It discusses the third-country equivalence process, the competence of the CJEU to review equivalence decisions, and also recent EU legislative developments occurring with respect to the oversight of third-country CCPs (a sector that is vital in relation to the overall stability of the financial system). It suggests that a number of difficulties may arise for the UK in bringing such legal applications but that in theory some types of executive and legislative action could be open to legal review. This section's analysis directly connects to the question then posed in the article's subsequent sections: which forum should be used to adjudicate on such disputes?

\section{B Equivalence: the Process}

Equivalence is the concept used by the EU to determine if a third country's regulatory and supervisory requirements are deemed equivalent to that of the EU's. When the UK becomes a third country, it will be required to use these third country/equivalence mechanisms (where these exist) to secure limited access to the single market. This is an imperfect regime; there is no single framework underpinning EU equivalence decisions, they are unilateral and discretionary decisions, and are especially designed towards the protection of EU interests. ${ }^{30}$

It can also be a slow and unpredictable process. On the one hand the EU can sometimes be witnessed adopting a pragmatic approach to equivalence decisions (including concerning its treatment of access by US CCPs to the EU derivatives markets and vice versa). ${ }^{31}$ On the other, the recent time-limited and conditional equivalence decision on the Swiss stock exchanges illustrates a more inflexible stance (in contrast, the US and also the Australian exchanges were recognised on an unlimited basis). ${ }^{32}$ The EU justified its approach based on the tightly interwoven nature of the Swiss/EU relationship and the knock-on implications for market access compared with a jurisdiction such as Australia, which would never be

\footnotetext{
${ }^{29}$ HM Government, Enforcement and Dispute Resolution: A Future Partnership Deal (August 2017) 7.

${ }^{30}$ Commission, EU Equivalence Decisions in Financial Services Policy: An Assessment SWD(2017) 102 Final (2017) 5.

${ }^{31}$ Commission, Implementing Decision on the Equivalence of the Regulatory Framework of the USA for CCPs Authorised and Supervised by the CFTC L70/32 (March 2016) (referring to the US rules delivering substantive outcomes equivalent to the EU provisions); N. Moloney, 'Brexit and Financial Services: (yet) Another Re-Ordering of Institutional Governance for the EU Financial System?' (2018) 55 CMLR 175, 184.

${ }^{32}$ Commision, Implementing Decision on the Equivalence of the Legal and Supervisory Framework of the USA for National Securities Exchanges and Alternative Trading Systems (2017/2320); Commission, Implementing Decision on the Equivalence of the Legal and Supervisory Framework in Australia Applicable to Financial Markets (2017/2318).
} 
accessing the EU market in the same way. ${ }^{33}$ The Swiss equivalence decision was extended for a further six months in December 2018; $;^{34}$ however, this decision then lapsed without the EU renewing it on 30 June 2019. ${ }^{35}$ As will be discussed further below, all such developments were also connected to the Swiss/EU constitutional negotiations, suggesting that equivalence decisions may take on political salience, reflecting wider EU motivations in play. ${ }^{36}$

The process also lacks transparency. Third countries have no 'right' to be assessed, and although the criteria for performing the equivalence assessment will be contained in the relevant financial services legislation, the Commission decision will be discretionary in accordance with that empowerment. ${ }^{37}$ The Commission's 2017 Statement on Equivalence also suggests that in addition to the specified equivalence criteria and the Treaty objectives, it factors in 'wider external policy priorities and concerns' including the promotion of common values and shared regulatory objectives at the international level (such as risks to financial stability and investor protection). ${ }^{38}$ As Wymeersch argues, this again suggests that such assessments can be based on political aspects, as evidenced with the decisions on Swiss stock exchange equivalence, which did not appear to have a valid legal basis. ${ }^{39}$

Where a positive equivalence outcome is denied, there will be no formal decision, and the grounds of refusal will remain unknown to the wider public. The Commission also has the unilateral discretion to withdraw an equivalence decision on short notice. ${ }^{40}$ Although this system is also the quid pro quo for the fact that third countries can make their own determinations on whether to grant EU access to their markets, and can change their own regimes as they see fit, it remains an imperfect system for governing a future (potentially) intimate UK/EU relationship. ${ }^{41}$

C Can the CJEU Review Equivalence Decisions?

\footnotetext{
${ }^{33}$ G. Baur (n 6); 'EU Doesn't See Case for Green Light on Swiss Stock Exchange' Bloomberg (28 November 2018).

${ }^{34}$ Commission, Implementing Decision of 20 December 2018 on the Equivalence of the Legal and Supervisory Framework Applicable to Stock Exchanges in Switzerland (2018/2047).

${ }^{35}$ See e.g. 'EU-Based Traders Caught in Swiss ‘Equivalence' Spat' Financial Times (30 June 2019).

${ }^{36}$ European Parliament, Report on Relationships between the EU and Third Countries Concerning Financial Services (A8-0263/2018) (July 2018) 6 (expressly referring to the clear political dimension). See also Commission, EU Equivalence Decisions in Financial Services Policy: An Assessment SWD(2017) 102 Final that does not expressly refer to Brexit although states that 'equivalence is not a vehicle for liberalising international trade in financial services'.
}

${ }^{37}$ K. Alexander (n 7) 210-211.

${ }^{38}$ Commission, EU Equivalence Decisions in Financial Services Policy: An Assessment SWD(2017) 102 Final 9; E. Wymeersch, 'Third-Country Equivalence and Access to the EU Financial Markets Including in Case of Brexit' (2018) 4 Journal of Financial Regulation 209, 225.

${ }^{39}$ E. Wymeersch (n 38) 225.

${ }^{40}$ Commission, EU Equivalence Decisions in Financial Services Policy: An Assessment SWD(2017) 102 Final; N. Moloney, 'Brexit, the EU and Its Investment Banker: Rethinking 'Equivalence' for the EU Capital Market' (n 12) 14.

${ }^{41}$ ESFRC, How to Mitigate the Shock of Brexit to Financial Services in the EU (Statement No. 46) (April 2019) 4. 
With respect to challenging Commission equivalence assessments, the CJEU competence will depend on the specific case in question. In the situation where the Commission simply takes no action at all, and is under no obligation to do so, the possibility for legal action (certainly at the CJEU) would currently appear to be limited. ${ }^{42}$ The UK will not be able to 'force' any equivalence process to commence; nor easily challenge the Commission for failing to act where it is not required to do so.

Where a Commission equivalence decision has been made, its legality may be open to judicial review by the CJEU. Under article 263 TFEU, the Court has the jurisdiction to review the legality of acts of the EU institutions and can annul illegal acts. ${ }^{43}$ In terms of standing, such challenges can most easily be brought by a Member State, or one of the main EU institutions ('privileged applicants'). ${ }^{44}$ In principle, any natural or legal person (whether from a EU or a non-EU State) can also have standing as 'non-privileged' applicants although restrictive standing conditions are placed on such persons under article 263(4). ${ }^{45}$ Such requirements have generally also been interpreted strictly by the CJEU, meaning the likelihood of securing standing is limited. ${ }^{46}$ Moreover although a non-privileged person (such as a UK firm) could try to satisfy the 'Lisbon limb' of article 263(4), which enables a challenge to a regulatory act (and which could cover equivalence decisions), there remain further technical hurdles to be met, which could still result in an action being rendered inadmissible. ${ }^{47}$

Taken together, when article 263(4) is applied to the UK, it will need to be a Member State to have standing (or to be treated 'as if' it were still a Member State, as is envisaged during the proposed transition period). As some challenges to equivalence decisions could emerge

\footnotetext{
${ }^{42}$ See European Parliament, Third-Country Equivalence in EU Banking Legislation (July 2017) 5.

${ }^{43}$ Although not in the financial governance domain, see e.g. C-362/14 Schrems $v$ Data Protection Commissioner EU:C:2015:650 where the CJEU found data equivalence arrangements with the US to
} be invalid. This led to a more restricted equivalence set-up being put in place.

${ }^{44}$ As privileged applicants, the Member States, Parliament, Council and Commission have automatic standing (they are presumed to have an interest in the legality of EU acts). There are also 'semiprivileged' applicants (the ECB, the Court of Auditors, and the Committee of the Regions) that can bring claims but only in relation to protecting their prerogatives.

${ }^{45}$ Art 263(4) provides that any such person can institute proceedings where the act is addressed to them; is of direct and individual concern; or they are directly concerned by a regulatory act that does not require implementing measures.

${ }^{46}$ Considerations behind this approach include floodgates concerns; see A. Albors-Llorens, 'Judicial Protection before the Court of Justice' in Catherine Barnard and Steve Peers (eds), EU Law (2nd edn, OUP 2017); see also e.g. S. Peers, How to Protect the Rights of UK Citizens in the EU27 after Brexit? Analysis of the Shindler Judgment (November 2018).

\footnotetext{
${ }^{47}$ See A. Albors-Llorens ( $\mathrm{n} 46$ ) section 3.2.4. In principle there could also be a connected art 277 TFEU plea of illegality (this is an incidental plea when proceedings are pending under another route) against the Level one regulation or directive. Albors-Llorens identifies that the Lisbon reforms in art 263(4) offer an important new dimension to the use of this plea meaning this could be more viable. In this regard see the Inuit litigation, although these cases also reiterate the hurdles to gaining access (in Inuit I, the Lisbon limb was held inapplicable and the applicants did not surpass the general standing test; in Inuit // the question of admissibility was not explored and the application failed on substantive grounds), Case C-583/11P Inuit Tapiriit Kanatami v Parliament and Council (Inuit I) EU:C:2013:625; Case T-526/10 Inuit Tapiriit Kanatami v Commission (Inuit II) EU:T:2013:215 (a subsequent appeal was also dismissed); A. Albors-Llorens ( $\mathrm{n}$ 46) section 6; A. Albors-Llorens, 'Remedies against the EU Institutions after Lisbon: An Era of Opportunity?' (2012) 71 Cambridge Law Journal 507.
} 
during the transition period, this could enable the UK to commence an action at the CJEU. Subsequent to this, however (and although subject to what agreements are finalised between the UK and EU), recourse to the CJEU could then depend on another sympathetic Member State or EU institution contesting the legality of a particular decision. As already observed, although in principle a UK firm could try to bring a challenge as a non-privileged applicant, this would be subject to surpassing the strict standing rules.

With respect to an EU institution bringing a legal complaint, it could be the case that the European Parliament (the 'Parliament') chooses to bring an action. This EU institution is playing an increasingly prominent role in EU financial governance, and it has called for the Commission to be 'held more directly accountable'. ${ }^{48}$ It also recently advocated introducing a more consistent, transparent and practical equivalence framework. ${ }^{49}$ At the same time, this is not a fail-safe mechanism. How enthusiastic the Parliament may be to come to a former Member State's aid can be queried, especially given its focus on ensuring the robustness of the EU's financial governance framework. ${ }^{50}$

C What Kinds of Equivalence Complaints could be contemplated?

In terms of the different kinds of complaints that could emerge, a number of Brexit-shaped equivalence applications could be envisaged. These could be of a procedural nature, such as the Commission's failure to commence an equivalence assessment, or that there is a lengthy delay in the Commission making its equivalence decision. In line with the above analysis, however, it is by no means clear that such omissions to act could be reviewed by the CJEU.

There could also be substantive complaints regarding a final decision, including a denial of a positive equivalence determination, or a decision to revoke an equivalence decision. In line with the precedent concerning the Swiss stock exchange decisions, contentions could include that an equivalence decision, or its revocation, does not have a valid legal basis. Admittedly there are clear difficulties in making such a case given there is no requirement for a formal Commission decision where equivalence is denied. Yet in principle, a legal argument could be pursued via a comparison of the UK's regulatory and supervisory framework with that of the EU's. ${ }^{51}$ In line with the analysis explored above, such a comparative exercise could be used to advance an argument that (for instance) a particular decision has not been based on objective regulatory reasons in accordance with the relevant equivalence criteria in the legislation and the Treaty objectives. Rather (and connected to the article's earlier discussion on the equivalence process) the contention would be that it concerns unrelated factors and wider external policy priorities beyond the equivalence criteria and Treaty objectives (including the conduct of the UK/EU negotiations). ${ }^{52}$

\footnotetext{
${ }^{48}$ European Parliament, Report on the EU Role in the Framework of International Financial, Monetary and Regulatory Institutions and Bodies A8-0027/2016 (2016).

${ }^{49}$ European Parliament, Report on Relationships between the EU and Third Countries Concerning Financial Services (A8-0263/2018) 7.

${ }^{50}$ See N. Moloney, “Bending to Uniformity': EU Financial Regulation with and without the UK' (n 16) 1361.

${ }^{51}$ E. Wymeersch (n 38) 225.

${ }^{52}$ A. Lang (n 8) section III, 202, 215; Commission, EU Equivalence Decisions in Financial Services Policy: An Assessment SWD(2017) 102 Final 9. Note that reciprocal challenges, albeit on a lesser scale, could also present themselves regarding UK equivalence assessments of EU frameworks with respect to gaining access to the UK markets, although the UK has so far been signalling a willingness to recognise
} 
A further flashpoint within financial governance could concern the EU's legislative policy on CCP oversight. Although as identified above, the UK won a limited victory at the CJEU in relation to the location policy concerning euro-dominated contracts, tensions have escalated since the Brexit vote, not least in relation to concerns about euro-clearing occurring offshore in the UK. ${ }^{53}$

Although arcane, the CCP sector is extremely important to the overall stability and effectiveness of the financial system as a whole. In particular, due to the post-crisis developments to centrally clear over-the-counter contracts, CCPs can now be systemically important entities. Moreover, the City of London is the key location for CCP services in the $\mathrm{EU}$, and the largest clearing houses engaging in euro-denominated transactions are located in the City (for instance in relation to interest rate derivatives in the EU, around three quarters (of total outstanding notional) of these trades have been estimated to take place between a group of dealers and/or banks all based in the City). ${ }^{54}$ As the UK's pre-Brexit challenge to the ECB's location policy demonstrated, this was a contentious area even before the referendum and also explains why, with Brexit looming, these tensions have now been reignited.

Indeed since the earlier CJEU CCP ruling, and in light of Brexit, the ECB has proposed amending its statutes so that it has authority to supervise CCPs and to ensure the UK's CJEU argument can no longer be used..$^{55}$ Moreover, although ESMA has granted one-year licences to London's clearinghouses to enable them to continue to clear trades in the event of any 'hard' Brexit, ${ }^{56}$ there are CCP Proposals (on which provisional agreement has recently been reached) that envisage tougher oversight of third country CCPs (sometimes referred to as 'EMIR 2.2'). This includes increased supervisory and enforcement competence for ESMA with respect to third country CCPs. ${ }^{57}$ ESMA's mandate is subject to a number of detailed procedural conditions, but the outcome of the process could in effect compel systemically important UK-based CCPs to relocate to a Member State in order to have market access. ${ }^{58}$

EU frameworks as equivalent going forward, FCA, The Temporary Permissions Regime for Inbound Passporting EEA Firms and Funds - Our Approach (July 2018).

${ }^{53}$ N. Moloney, 'Brexit and Financial Services: (yet) Another Re-Ordering of Institutional Governance for the EU Financial System?’ (n 31) 181-182.

${ }^{54}$ K. Lannoo (n 20) 1; European Systemic Risk Board, Shedding Light on Dark Markets: First Insights from the New EU-Wide OTC Derivatives Dataset (May 2016).

${ }^{55} \mathrm{ECB}$, Recommendation for a Decision Amending Article 22 of the Statute of the European System of Central Banks and of the ECB C212/14 (2017); Y. Mersch, ECB: Euro Clearing - the Open Race (May 2018); K. Lannoo, Derivatives Clearing and Brexit: ECMI Policy Brief No. 25 / November 2017 (2017). So far the ECB's move has been backed by the Commission, and the Parliament's relevant committees.

${ }^{56}$ ESMA, ESMA to Recognise Three UK CCPs in the Event of a No-Deal Brexit (ESMA71-99-1114) (2019); 'EU Derivatives Traders to Get Hard-Brexit Reprieve' Financial Times (18 February 2019).

${ }^{57}$ Commission, Proposal for a Regulation as Regards CCPs and Requirements for the Recognition of Third-Country CCPs COM(2017) 331 (2017), art 25(2c).

58 Ibid art 25(2c). In this regard, the Parliament's report on the Commission Proposals retained the socalled 'location policy' but proposed means to make such decisions more proportionate and to introduce a more evidence-based analysis (costs and benefits) into the process. The Council's 
Such developments could pave the way for a future judicial challenge. For instance, an application could emerge from ESMA's operational approach to its supervisory and enforcement responsibilities, including whether its mandate breaches its Treaty competency. A substantive challenge could also derive from an ESMA recommendation (and the accompanying Commission decision) to refuse CCP recognition. In line with the above analysis, arguments could be advanced that such decisions are not in line with technical, objective criteria, but concern wider political or commercial strategy (a 'relocation weapon' employed if, for instance, the UK/EU relations deteriorate). ${ }^{59}$

Again, the UK can only directly bring such challenges via the CJEU during the transition period. Following this (and, again, subject to what agreements are concluded between the UK/EU), with respect to CCPs, it could the case that other Member States are willing to commence legal action, such as alleging a breach of Treaty competency if disgruntled at ESMA's increased direct operational ambit. Indeed it could be argued that the ESMA 'location policy' decision involves ESMA making policy choices with distributional consequences (including raising costs for businesses, which could impact some more than others), and which pushes at the boundary of ESMA's remit. ${ }^{60}$ This is not least given that CCPs are often considered a special case of systemically important market entities compared with many other elements of the financial system. Again, at the same time, there are no guarantees that another Member State would bring a case that includes championing the cause of a jurisdiction that has chosen to depart the Union.

Should the CJEU be the Final Arbiter?

This section has illustrated the different types of judicial complaints that may emerge with respect to financial services and that the UK will face various impediments bringing future applications. This raises the related question; specifically, what is the appropriate forum to hear such legal challenges? On the one hand, arguments can be advanced that the CJEU should the arena for resolving post-Brexit disagreements. First, the CJEU is the authority on EU law within the EU order. Next, given Brexit's unique circumstances, where the UK is leaving an international organisation with which it wishes to have ongoing amiable relations (and where it was previously represented in its institutions), this could justify the CJEU being granted jurisdiction over Brexit-related disputes. ${ }^{61}$ Further, to specifically cater for the UK's situation, additional protections could be built into the system. For instance the UK could have the right to intervene in all cases before the CJEU as well as being conferred the right

Compromise also described such decisions as a 'last resort' and in line with the Parliament, sought to ensure decisions will be made on a quantitative technical assessment, European Parliament, Report on CCP Proposals A8-0190/2018 (May 2018); ECOFIN, Presidency Compromise Proposal 14496/18 (November 2018).

${ }^{59}$ Davis Polk, Proposals to Amend the EMIR Supervisory Regime (June 2017).

${ }^{60} \mathrm{HM}$ Treasury, Letter from John Glen to European Scrutiny Committee on CCP Proposals (21 November 2018); D. Mügge, 'The European Presence in Global Financial Governance: A PrincipalAgent Perspective' (2011) 18 Journal of European Public Policy 383, 386.

${ }^{61}$ A. Arnull, Written Evidence to House of Lords European Union Committee: Dispute Resolution and Enforcement after Brexit (January 2018). 
to nominate an ad hoc judge on cases concerning the interpretation and application of Brexit law. ${ }^{62}$

As the next section will explore, such contentions advance the case for a central role for the CJEU over the shorter term, given that any such disputes may directly concern questions of EU law, and where the CJEU's input may be especially valuable. Over the longer term, however, as a matter of principle, it may be undesirable for the CJEU to be selected as the final forum for resolving future UK/EU disagreements. Specifically, a standard feature of many international agreements is that they do not tend to give one party jurisdiction over the other when resolving disputes. ${ }^{63}$ In this regard, the alternative of a neutral arena, rather than the CJEU, for post-Brexit dispute settlement would offer a fair and impartial means of resolving disagreements. ${ }^{64}$ Moreover, such a system could also be tailored in order to provide for the option of a party making a voluntary reference to the CJEU.

In this regard, the following section considers the proposed dispute settlement provisions within the UK/EU Draft documentation. Although its status remains hazy, and it has failed to be approved by the UK House of Commons on multiple occasions, its dispute settlement aspects merit reflection. They amount to a delicate combination of political discussion, arbitration, plus a role for the CJEU. This analysis also provides the launching pad for the article's next part, where, given the unpredictable outcome of the UK/EU negotiations, and the various red lines on the CJEU, alternative institutional structures are examined with respect to regulating the UK/EU's relationship over the longer term.

\section{A Proposed Dispute Settlement: Brexit and Beyond}

B The (Proposed) Transition

There are three potential stages to consider in relation to dispute resolution: the proposed transition period; the Withdrawal Agreement as it applies after the transition period; and the future arrangements to govern UK and EU relations over the longer term. The Draft UK/EU Withdrawal Agreement (the 'WA') provides that during any transition period, the UK is treated as if it were still a Member State and the CJEU will continue to have jurisdiction with respect to any proceedings. In this regard, during the envisaged transition period, the UK can continue to refer cases to the CJEU, bring cases or intervene. ${ }^{65}$

\section{B The Draft Withdrawal Agreement}

Many provisions within the Draft Withdrawal Agreement ('WA'), including most of the dispute resolution provisions only apply from the end of the transition period. There are

\footnotetext{
${ }^{62}$ House of Lords European Union Committee, Dispute Resolution and Enforcement after Brexit (May 2018) para 118; A. Arnull (n 61).

${ }^{63}$ HM Government (n 29) 4-5.

64 lbid 6.

${ }^{65}$ Draft UK/EU Withdrawal Agreement (as Endorsed by the European Council) 2018, see in particular arts $86-87$ and art 89 which also provide that where the Commission considers the UK has failed to comply with Treaty obligations or those under the Draft Treaty, it can bring a claim within four years after the end of the transition; see also art 127(6); art 131.
} 
particular provisions to enable UK courts to request a preliminary CJEU ruling on the interpretation of the provisions on citizens' rights in the WA where necessary for the UK court to give judgment (this jurisdiction runs for an eight year period post-transition). ${ }^{66}$ The CJEU also has jurisdiction with respect to particular financial settlement provisions (no temporal limit specified). ${ }^{67}$ These elements aside, the Draft WA then contains separate provisions in relation to dispute resolution procedures concerning disputes arising under the Agreement. $^{68}$

The proposed framework draws on existing models, including the WTO system, as well the arrangements suggested in the Swiss/EU draft agreement (both examined later in the article). Under the WA, the UK and EU must first seek to resolve issues via consultation with the to-be established political forum, the Joint Committee (which will comprise of representatives from the UK and the EU). ${ }^{69}$ If no mutually agreed solution has been found within three months, or earlier if both agree, then either can request the creation of an Arbitration Panel, which will comprise of five members. Each shall nominate two members from a list generated by the Joint Committee and the chair shall be selected by consensus. The Panel will aim to reach agreement by consensus, failing which there will be a majority vote. $^{70}$

The arbitration process is based on general international law, although where a dispute raises an issue on a question of interpretation of a concept of EU law (which includes such a question in the WA, plus questions concerning the UK complying with CJEU judgments during the transition, and four years subsequent where this concerns the UK's failure to fulfil the WA or EU Treaty obligations) the Panel shall refer this to the CJEU. The ruling will be binding on the Panel ${ }^{71}$ (although there are no specific tools by which the CJEU could force the Panel to comply with the ruling).

The role of the CJEU is tempered to an extent in the WA. Where the Panel decides that the issue in question does not concern the interpretation of EU law or the UK's obligations under the Treaties or the WA, it can refuse to request the CJEU ruling. In this situation, it shall provide a reasoned decision, and either party can request a review, in which case the Panel will a give a reasoned assessment. ${ }^{72}$ If the Panel decides EU law is not engaged, there can be no further request for a CJEU ruling. ${ }^{73}$

\footnotetext{
${ }^{66}$ Ibid art 158.

${ }^{67}$ Ibid art 160.

${ }^{68}$ Ibid arts 167-181; Annex IX, Part A (procedural rules); Part B (Code of Conduct for Panel members).

${ }^{69}$ Ibid art 164.

${ }^{70}$ Ibid art 171; 180 (and with no dissenting opinions to be published).

${ }^{71}$ Ibid art 174; Opinion 1/92 (only the CJEU can give an interpretation of EU law that binds the Member States and EU institutions); see also C-284/16 Slovak Republic $v$ Achmea BV ECLI:EU:C:2018:158 where an arbitration clause between two Member States (prior to the accession of one of them to the EU) was found to be incompatible with EU law as it removed disputes on the application and interpretation of EU law from the mechanisms within the EU framework.

72 Draft UK/EU Withdrawal Agreement (as Endorsed by the European Council) 2018, art 174(2).

${ }^{73}$ Commission, Brexit Negotiations: What Is in the Withdrawal Agreement (Memo 18/6422) (2018); B. Fowler, Red Line Crossed? The Withdrawal Agreement's Arbitration Clause (November 2018).
} 
The final Panel ruling binds both sides. ${ }^{74}$ If there is non-compliance, the Panel can grant temporary remedies (including penalty payments and lump sums). In the event of continued failure to comply or of non-payment, the complainant can temporarily suspend any provision in the WA (other than those on citizens' rights, or parts of any other agreement between the EU and UK). ${ }^{75}$ These processes are also broadly in sync with the WTO model.

Overall, the Draft WA's dispute resolution provisions can be regarded as an attempt at a careful balancing act between the UK and the EU's red lines on the CJEU, using a combination of (mainly) political channels plus arbitration and the input of the CJEU where required. Moreover, unlike the Commission's original draft of the WA, which envisaged a simple formula of political channels plus a central role for the CJEU, the arbitration framework is an amendment the UK secured from the EU. ${ }^{76}$ Be that as it may, the question as to whether or not EU law is engaged in a particular scenario may not always be clear, and there could be the potential for Panel decisions on the relevance of EU law (in conjunction with the less prominent role for the CJEU) to prove controversial. ${ }^{77}$ At the same time, however (as observed above) disputes involving the WA also have much potential to involve questions of EU law, necessitating the CJEU's contribution. In this regard, over the shortmedium term, several more CJEU judgments on the UK may be envisaged. ${ }^{78}$ On the other hand, as Peers argues, it may be the case that such questions can be resolved politically; analogous CJEU provisions in EU agreements with other third countries have not been used in practice. ${ }^{79}$

The Draft Political Declaration that accompanies the Draft WA is a light-touch and nonbinding text. Yet it does offer some suggestions as to the general direction of travel for the future arrangements. ${ }^{80}$ With respect to the dispute resolution provisions, it proposes that these be based on those in the Draft WA (with informal bilateral discussions and consultations as a first step). ${ }^{81}$ Where a dispute raises an issue regarding the interpretation of EU law, the Declaration proposes that the Arbitration Panel should refer such questions to the CJEU for a binding ruling (and that the Panel then decide the dispute in accordance with this). ${ }^{82}$ Nonetheless, with respect to CJEU referrals the use of the softer term 'should' in the

\footnotetext{
${ }^{74}$ Draft UK/EU Withdrawal Agreement (as Endorsed by the European Council) 2018, art 175.

${ }^{75}$ Ibid, art 178; S. Peers, To Boldly Go? Analysis and Annotation of the EU/UK Future Relationship Declaration (December 2018).

${ }^{76}$ Commission Draft Withdrawal Agreement TF50 (2018) 33 (February 2018) art 162; D. Jancic, Brexit and Dispute Resolution: the UK's mini victory? (2018).

${ }^{77}$ B. Fowler (n 73).

${ }^{78}$ S. Peers, Dispute Settlement and the Brexit Withdrawal Agreement (December 2018).

79 Ibid.

${ }^{80}$ Note that Article 218(11) TFEU also allows for the terms of an envisaged international agreement to be challenged by a Member State or EU institution at the CJEU before it is concluded, see House of Lords European Union Committee (n 62) chapter 3.

${ }^{81}$ Political Declaration on the Future UK/EU Relationship 2018, Section D.

${ }^{82}$ Ibid para 134. Peers argues that EU provisions may prove less relevant under the future relationship as the future relationship treaties are less likely to reference EU law, S. Peers, To Boldly Go? Analysis and Annotation of the EU/UK Future Relationship Declaration. At the same time, this may not be the
} 
Declaration (rather than the use of the definitive 'shall' contained in the WA) points towards more flexibility in the referral process.

Where a party fails to comply with a Panel's ruling within a reasonable period, the other party can seek financial compensation or take proportionate and temporary measures include the suspension of its obligations within the scope of the future relationship. ${ }^{83}$ Again, such measures are similar to those under the WTO system.

Taken together, the Draft WA and Political Declaration envisage a system of political consultation, arbitration, plus a role for the CJEU. Yet, at the time of writing, their status remains in limbo. Moreover, the Political Declaration has no formal legal status, and understandably leaves the specifics with respect to any future UK/EU legal relationship largely unclear.

This is a legally intricate and politically delicate area and it is exacting to develop a framework that reflect both the UK's and the EU's expectations. In this regard, the Draft WA amounts to a fragile accord, with its focus on arbitration plus the use of the CJEU on questions of EU law. Moreover, as identified above, given that WA disputes may directly concern EU law, the CJEU's input would appear warranted (and it could also be the case that many such issues can be resolved politically).

Over the longer term, however, (in line with the earlier analysis) it is suggested that the CJEU should not be the institution in charge of resolving equivalence and other legal disputes arising between the two sides. ${ }^{84}$ Although the case can be made for selecting it as the forum for post-Brexit dispute resolution (with additional protections introduced to cater for the UK's position) ${ }^{85}$ it is undesirable for one party to an international agreement to be responsible for marking its own homework. Rather, international agreements may be enforced outside the EU by other entities including via judicial, quasi-judicial and political bodies, and this would avoid one side being granted direct jurisdiction over the other.

Accordingly, as explored in the following section, alternative form of institutional structure could be utilised to engage in oversight and dispute settlement concerning the range of decisions and determinations taking place. At the same time, the UK in particular should remain mindful as to the realities; most notably, the EU will be reluctant to start from scratch and engage with blue-sky thinking. Rather, as witnessed with its approach in the UK/EU Draft WA, it has a preference for using pre-existing templates. In this regard, the EU will likely prove more partial to off the shelf frameworks. ${ }^{86}$ Structures the EU has previously considered include that in the Swiss/EU proposed framework, the EFTA Court, and also the WTO forum.

case so much in the field of financial governance, where a complex system of laws govern the UK/EU access relationships and (certainly currently) draw extensively on the EU rule-book.

${ }^{83}$ Political Declaration on the Future UK/EU Relationship 2018 para 135.

${ }^{84}$ HM Government (n 29) 4-5; S. Blockmans and G. Van der Loo, Brexit: Towards an 'EFTA-Like' Dispute Settlement Mechanism, CEPS Commentary (August 2017) 2.

${ }^{85}$ A. Arnull (n 61).

${ }^{86}$ G. Baur (n 6). 
Alternative Models

The choice of dispute settlement mechanism is a legal and technical issue as well as a political one. It also depends on the type of future partnership that emerges between the UK and EU, which could vary depending on the area in question as well as the issues generated by the wider Brexit tapestry. With respect to the field of financial governance, in principle, a close to relatively-close relationship may be conceivable between the UK and EU. To an extent this comes through in the Draft Political Declaration; it demonstrates a relatively strong degree of commitment with the wording that both parties 'will have equivalence frameworks' in place rather than that they 'should have' them in place. At the same time, a weaker degree of commitment is then suggested via the use of 'should' rather than 'will' with respect to both sides commencing the assessment of each other's equivalence regimes, and in relation to the principles underpinning future regulatory and supervisory cooperation. ${ }^{87}$ Nonetheless, on a holistic and historical view, the deep interconnections between the two jurisdictions over the decades with respect to financial governance should mean that a form of close cooperation is the aim. This is not only in relation to mutually common pursuits including ensuring financial stability and investor protection, but also to enable the EU and UK to offer a stronger voice on the world stage, including within the international standard setting bodies.

If such an affiliation can be envisaged, then effective oversight and dispute resolution mechanisms are important to ensure they continue to conform to their regulatory and supervisory arrangements. ${ }^{88}$ In such a scenario, it may be that a combination of political channels and arbitration can provide much of the heavy lifting. At the same time, and as discussed in the introduction, an intimate UK/EU arrangement is also likely to be conditional (on the EU's side) on there being a role for the CJEU. At the other end of the spectrum, if there is a no deal scenario, or if mutual relations subsequently collapse down the line, there will again be a need for robust dispute settlement systems. This will necessitate an independent quasi-judicial or judicial forum of a different kind, potentially drawing inspiration from the WTO's highly regarded system.

This section considers the strengths and shortcomings of three frameworks as well as the associated glitches that may arise when seeking to fashion a future dispute resolution system. First, it discusses the bilateral Swiss/EU proposed framework. This accords with the elements in the UK/EU WA and its approach can also be found in other EU/external agreements. In this regard, the price of accessing the internal market is the presence of the CJEU. At the regional level, it considers the European Free Trade Area ('EFTA') Court, focusing on the docking scenario. Although more elaborate, it has relevance for the UK and its financial sector, including the absence of any political integrationist agenda. Yet if this proves to be a non-starter, and if negotiations stall more fundamentally, the international WTO settlement system merits consideration. This is a well-developed quasi-judicial model,

\footnotetext{
${ }^{87}$ Political Declaration on the Future UK/EU Relationship 2018, paras 37-39; S. Peers, To Boldly Go? Analysis and Annotation of the EU/UK Future Relationship Declaration (n 82).

${ }^{88}$ N. Moloney, 'Negotiating a Financial Services Deal' (LSE Brexit Special 6: Policy Briefing 25 (2017)).
} 
and could play an oversight role in relation to EU/UK equivalence assessments, and be a structure for challenging any arbitrary decisions.

Swiss/EU relations have historically been governed via a large range of complex bilateral sectoral agreements. At present, in the main, the application and interpretation of these arrangements is not overseen by the CJEU, rather disagreements are resolved through political and diplomatic dispute resolution via the Swiss/EU Joint Committees. ${ }^{89}$ In recent years, however, these arrangements have been the subject of much criticism from the EU. ${ }^{90}$ Issues include the static and judicious application of EU rules by the Swiss, whereby Switzerland selectively applies parts of the EU acquis rather than automatically amending its domestic laws as EU law evolves. ${ }^{91}$

Since 2008, the EU has demanded an ambitious institutional overhaul (along the lines of the EEA regime), failing which the EU will not negotiate new market access agreements with Switzerland (and no significant new agreements have been concluded since 2008). ${ }^{92}$ Negotiations are ongoing, and the draft Swiss/EU Framework takes a more dynamic approach to facilitate agreements being updated in line with EU law developments. Similar to the UK/EU Draft WA, the framework proposes referring disputes to an arbitration Panel where the (current) relevant Joint Committee cannot resolve this. Questions on the interpretation of EU law are to be referred to the CJEU, whose ruling will bind the Panel, and it will resolve the dispute based on the CJEU's interpretation. ${ }^{93}$ Pirker identifies that the draft provisions provide that an arbitration Panel will make a referral where interpretation of that norm is relevant to resolve the dispute and necessary to enable the tribunal to take a decision' ${ }^{94}$ In theory, this grants the Panel a degree of flexibility, in a similar vein to that of the Panel's under the UK/EU WA. ${ }^{95}$ If a party fails to comply with the arbitral decision, the other party can take compensatory measures, including suspension of aspects or all of an agreement. The proportionality of such elements can also be reviewed by the Panel. ${ }^{96}$

\footnotetext{
${ }^{89}$ Institute for Government, Brexit and the European Court of Justice (June 2017).

${ }^{90}$ Council, General Affairs Council Conclusions: EU Relations with Non-EU Western European Countries (December 2014).

${ }^{91}$ Centre for European Reform, Brexiting Swiss-Style: The Best Possible UK-EU Trade Deal (April 2017)
} 9.

${ }^{92}$ C. Tobler, 'One of Many Challenges after 'Brexit': The Institutional Framework of an Alternative Agreement - Lessons from Switzerland and Elsewhere?' (2016) 23 Maastricht Journal of European and Comparative Law 575, 578-579; Institute for Government, Dispute Resolution after Brexit (October 2017), chapter 6 .

${ }^{93}$ Draft Framework Agreement between Switzerland and the EU (November 2018) art 4(2) and art 10(3), see further A. Tomás, The Settlement of Disputes Arising from the UK's Withdrawal from the EU: Study for the European Parliament (2017) 27; Swiss Federal Council, Federal Council Decides to Launch Consultations on the Draft Institutional Agreement (December 2018).

${ }^{94}$ B. Pirker, Dispute Resolution and Interpretation in the Draft Framework Agreement between Switzerland and the EU (December 2018). Pirker also identifies that there is no possibility for a party to request the Panel review its assessment in the Swiss/EU draft.

95 Opinion 1/91 ECLI:EU:C:1991:490; Opinion 1/92; B. Pirker (n 94).

${ }^{96}$ Draft Framework Agreement between Switzerland and the EU (November 2018) art 10; B. Pirker ( $\mathrm{n}$ 94). 
The Swiss/EU approach is often referred to as the 'Ukraine' model as the elements can be found within the EU/Ukraine association agreement, and it is also in evidence in association negotiations with the 'AMS States' (Andorra, San Marino, and Monaco). ${ }^{97}$ In conjunction with the EU/UK framework, such arrangements reflect the EU's preference for engaging with existing models rather than creating bespoke mechanisms. Writ large, it points to a new paradigm of dispute settlement developing in EU/external relationships with its close geographical neighbours, where their close vicinity impacts on the nature of the envisaged arrangements. Connected to this, however, is the inequality between the parties' bargaining positions, where the quid pro quo for gaining EU market access is the proviso of a significant institutional role for the CJEU. ${ }^{98}$ This also reflects the view the CJEU has consistently taken that it is the full and final authority on EU law. No other body should have jurisdiction to give definitive authority on such provisions. ${ }^{99}$

As with the UK, the proposed role of the CJEU has not been warmly welcomed in Switzerland; it does not want an institutional architecture where it has to relinquish formal sovereignty. More generally, however, the clear parallels between the Swiss/EU developments can only be taken so far; there remain important differences. Particularly in relation to financial governance, the Swiss situation has evolved from being a system quite apart from the EU's towards one now seeking greater integration with it. ${ }^{100}$ In contrast, UK financial governance currently conforms to the EU acquis, but following its exit, future regulatory and supervisory divergence may be anticipated over the longer term. ${ }^{101}$ Accordingly analogies can only be taken so far with respect to the translation of the institutional architecture from the Swiss/EU context to the UK/EU situation. Specifically (and although caveated by the recent breakdown in Swiss/EU relations following the lapse of the Swiss stock exchange equivalence decision), Switzerland has generally placed great value on the importance of single market access and has mainly been open to aligning its legislation with that of the EU's. In contrast, following Brexit, the UK will be seeking to pursue a new arrangement with the EU, which is not conditional (on the UK's side) on the full harmonisation of its laws with those of the EU's or on an institutional structure that requires disputes to be submitted to the CJEU. ${ }^{102}$

Regional: Bespoke Joint Court?

Moving to the regional level, at first glance, a joint UK-EU Court to interpret the Withdrawal Agreement and Future Relationship could offer a sensible compromise, as it would place the two sides on an equal footing. The predominant stumbling block is the CJEU, which is regarded as unlikely to accept this option. ${ }^{103}$ In particular, the CJEU rejected a proposal for a joint EU-EEA Court in the 1990s due to concerns that this could pose a threat to the EU's

\footnotetext{
${ }^{97}$ C. Tobler (n 92); C. Tobler, Oral Evidence to House of Lords: Dispute Resolution and Enforcement after Brexit (February 2018).

${ }^{98}$ C. Tobler, 'One of Many Challenges after 'Brexit': The Institutional Framework of an Alternative Agreement - Lessons from Switzerland and Elsewhere?' (n 9292).

${ }^{99}$ Opinion 1/91; Opinion 1/92; HM Government (n 29) 5; S. Blockmans and G. Van der Loo (n 84).

${ }^{100}$ K. Alexander (n 7) 152-3.

101 Ibid 153-4.

${ }^{102}$ G. Baur (n 6).

${ }^{103}$ House of Lords European Union Committee (n 62) para 33.
} 
legal order, even although CJEU judges were to sit on the joint Court. The CJEU took the view that the different goals of the EU and the EEA would mean the judges had to interpret the same provisions using different approaches, and this could make it tricky to retain an open mind in the CJEU if they had already encountered an issue in the EEA Court. ${ }^{104}$

The CJEU's 'very severe' Opinion was the subject of much criticism at the time. ${ }^{105}$ The essence of the CJEU's objection was that it viewed the creation of the EU-EEA Court as a threat to its own position as the supreme authority on EU law. ${ }^{106}$ Hartley notes that one can perhaps see the CJEU using its power here in order to protect its own institutional interests. ${ }^{107}$ This observation has clear salience with respect to the current UK/EU situation; the CJEU will wish to retain its exclusive competence within the EU legal order, accordingly the proposal of a Joint Court would appear to be a non-starter.

A further regional model that has been mooted is the possibility of the UK docking at the EFTA Court. EFTA is an intergovernmental (rather than supranational) organisation with an approach focused on free trade and economic integration between its members, the EU, and internationally. It has no political integrationist agenda. ${ }^{108}$ The EFTA Court has jurisdiction over the EFTA States that are party to the European Economic Area ('EEA') Agreement (Iceland, Lichtenstein and Norway), which incorporates EU law into the domestic law of these three EFTA States (with the exception of particular common policies such as fisheries and agriculture). ${ }^{109}$

The EFTA Court's jurisdiction is largely equivalent to the CJEU's: it applies and interprets EEA law for the EFTA States. It can provide advisory opinions to national courts, as well as ruling on infringement cases (brought by the EFTA Surveillance Authority ('ESA'), the executive element, broadly equivalent to the Commission). Currently the most important categories of cases are infringement actions brought by ESA against EFTA States concerning the EEA or in relation to the Surveillance and Court Agreement which establishes theses institutions (the 'SCA'); as well as requests for advisory opinions. ${ }^{110}$ The EFTA Court can, however, also rule on dispute settlement between EFTA States; actions for nullity of ESA decisions or for failures to act, which can be brought by a State, or a private party (subject to standing requirements); and damages claims can also be brought against the ESA. ${ }^{111}$

\footnotetext{
${ }^{104}$ Opinion 1/91, esp. paras 37 and 51.

${ }^{105}$ M. Clifton, EEA: Another Side to Europe (European Law Reporter, 2016$) 4$.

${ }^{106}$ H. Fredriksen, 'The EFTA Court' in Robert Howse (ed), The Legitimacy of International Trade Courts and Tribunals (CUP 2018) 139; T. Hartley, 'The European Court and the EEA' (2008) 41 International and Comparative Law Quarterly 841, 846-847.

${ }^{107}$ T. Hartley (n 106) 847.

${ }^{108}$ C. Baudenbacher, Written Evidence to House of Lords (2017 (BED0021)); Institute for Government, Could the UK Sign up to the EFTA Court after Brexit? (December 2017).

${ }^{109}$ Switzerland is an EFTA State but is not inside the EEA and is not subject to the jurisdiction of the EFTA Court. As witnessed earlier in section 5, it currently conducts its relations with the EU bilaterally rather than via the EEA agreement.

${ }^{110}$ H. Fredriksen (n 106) 148-9; Articles 31 and 34 SCA.

${ }^{111}$ Articles 32, 36, 37 and 39 SCA.
} 
The Court has three judges, one nominated from each EEA-EFTA jurisdiction. An institutional two-pillar structure is in place whereby Member State matters are dealt with via the normal national/EU framework (including the infringement procedure, and the preliminary ruling procedure); on the EEA/EFTA side there are parallel mechanisms in place via ESA and the EFTA Court. ${ }^{112}$ This structure has been endorsed by the CJEU (following the rejection of the EU-EEA Court). It was acceptable to the CJEU as there were express assurances that the CJEU case law would not be affected. ${ }^{113}$

In relation to the Brexit situation, rather than the UK directly signing up to the EEA (the Norway option), the UK could instead dock with the ESA and EFTA Court meaning that the UK would also not have to adopt the full EEA acquis. Rather it could simply become a member of the EEA institutions and the EFTA Court would be the forum for the settlement of disputes on the UK side. ${ }^{114}$

Most simply, the UK could adopt the two-pillar structure. Under the EFTA pillar, the UK would have the right to nominate its own ESA member and EFTA judge. The ESA would be responsible for monitoring compliance with the WA (and in principle, down the line, it could be in charge of overseeing the Future Partnership), and for checking that UK legislation (or at a minimum the EU elements) complied with the UK's obligations. Although this would involve interpreting and applying a new body of law, the EFTA institutions could be fairly well equipped to do so. ${ }^{115}$ The ESA would have the ability to bring infringement proceedings against the UK at the EFTA Court (sitting with the UK judge) in cases of non-implementation or other infringement cases concerning the UK-EU arrangements. ${ }^{116}$ The two-pillar set-up would also mean that the Commission and the CJEU would remain in charge of checking compliance and tackling complaints against EU actors.

In terms of remedies for infringement cases against EFTA States (where the EFTA Court can make binding decisions), article 33 SCA provides that EFTA States shall take 'all necessary measures' to comply with EFTA judgments. Unlike under EU law (article 260 TFEU), however, there is no SCA provision to impose a lump sum or penalty payment on EFTA States for cases of non-implementation of infringement judgements. Fredriksen observes that this is due to historical reasons; at the time the EEA negotiations, EU law did not have this possibility. ${ }^{117}$ The ESA can (and occasionally has) brought a State to the Court anew if there is noncompliance, although (to date) non-compliance is rare. In such an instance, however, the

\footnotetext{
${ }^{112} \mathrm{C}$. Tobler, 'One of Many Challenges after 'Brexit': The Institutional Framework of an Alternative Agreement - Lessons from Switzerland and Elsewhere?' (n 92) 580-581.

${ }^{113}$ Opinion 1/92.

${ }^{114}$ House of Lords European Union Committee ( $\mathrm{n} \mathrm{62)}$ (and as suggested by Carl Baudenbacher, President of the EFTA Court until 2017).

${ }^{115}$ Institute for Government, Dispute Resolution after Brexit (n 92) chapter 6, 52.

${ }^{116}$ Ibid chapter 6, 51-52.

${ }^{117}$ H. Fredriksen (n 106) 175. Note that if an EFTA State breaches EEA law the State is obliged to provide compensation for loss and damage caused to economic operators and individuals under the principle of State liability which is part of EEA law and this generally acts as an effective deterrent, Case E-19/14 EFTA Surveillance Authority v Norway [2015] EFTA Court Report 300 para 41.
} 
Court may issue a declaration that the State has failed to fulfil its obligations and order it pay costs. ${ }^{118}$

The EFTA docking model is undoubtedly more intricate, however, it can also provide more latitude. This could be an attractive structure for the UK if it is wishes to pursue a deeper relationship with the EU, whilst respecting the UK Brexit stance on the CJEU. ${ }^{119}$ Further, the EU already accepts the EFTA system; indeed, it proposed this to the Swiss as a possible solution in 2013, although this was rejected at the time by Switzerland (Baudenbacher notes that this was in all likelihood due to the Swiss Foreign Office following its traditional policy of preferring to avoid anything connected to the EEA system; moreover at that time, it also harboured a long-term vision of Switzerland joining the EU). ${ }^{120}$

Accordingly, given that the EU supports this system; the docking option could be a conceivable mechanism for future UK/EU dispute settlement. ${ }^{121}$ Moreover, as Baudenbacher argues, as the docking solution was not fully worked out with the Swiss, the granular elements would all be up for negotiation. ${ }^{122}$ Certainly, on the UK Government's red lines on leaving the CJEU, the EFTA Court acting as ultimate independent arbitrator on the UK side could have its attractions, including given that in practice, most EFTA disputes tend to be (currently) resolved diplomatically. ${ }^{123}$

The EFTA Court also does not formally recognise the primacy and direct effect of EU law (although, as discussed below, it is heavily influenced by it). Due to constitutional and political reasons in relation to judicial sovereignty, there is also no written obligation on domestic courts to refer cases to the EFTA Court, (it is a more 'partner-like) set-up, and EFTA preliminary rulings are advisory. ${ }^{124}$ The Court sometimes goes its 'own way' contrary to the CJEU, and a pragmatic stance can be evidenced in line with the ethos of the EEA Agreement, more in keeping with the UK's values. ${ }^{125}$

Despite this, it has a number of drawbacks. First, there would be considerable practical challenges in upscaling the system to tackle the considerably bigger caseload that would

\footnotetext{
118 H. Fredriksen (n 106110); see e.g. EFTA Surveillance Authority v Norway para 49.

${ }^{119}$ House of Lords European Union Committee (n 62) chapter 2; House of Commons Exiting the EU Committee, The Future UK-EU Relationship: Fourth Report of Session 2017-19 (2018) para 108; J. Odermatt, 'How to Resolve Disputes Arising from Brexit: Comparing International Models' (iCourts Working Paper Series, No 131, 2018).

${ }^{120}$ C. Baudenbacher, Judicial Independence (Springer 2019) 436.

${ }^{121}$ Institute for Government, Dispute Resolution after Brexit (n 92) chapter 6, 54.

${ }^{122}$ C. Baudenbacher, After Brexit: Is the EEA an Option for the United Kingdom? (October 2016) 5.

${ }^{123}$ G. Wright, EFTA Court Could Answer Post-Brexit Judicial Quandary (Politico) (January 2018).

${ }^{124}$ C. Barnard, 'Reciprocity, Homogeneity and Loyal Cooperation: Dealing with Recalcitrant National Courts?' in EFTA Court (ed), The EEA and the EFTA Court: Decentred Integration (Hart 2014) 157; C. Baudenbacher, Written Evidence to House of Lords; C. Baudenbacher, How the EFTA Court Works and Why It Is an Option for Post-Brexit Britain (2017). There are duties of loyalty but these are tricky to enforce.

${ }^{125} \mathrm{M}$. Clifton (n 105) 13. Examples have included the more liberal functional (rather than strict institutional) approach used in deciding whether a body is a court or tribunal that can make a reference, see e.g. Case E-23/13 Hellenic Capital Market Commission [2014] EFTA Court Report 88. para 34.
} 
emerge if the UK adopted this model. ${ }^{126}$ Next, the EEA-EFTA States, as well as the EU (and possibly the Member States) would have to support this docking system for the UK. ${ }^{127}$ Given the UK was a founding EFTA member, in the event the UK was required to re-join EFTA (which could be a requirement although this would be up for negotiation) this should be relatively straightforward. It would involve the decision of the existing members of the EFTA Council (the highest governing body where the four EFTA States are represented), which would be taken by consensus.

In relation to the EU's support for this model, a deeper complication emerges. EU approval would likely be conditional on the inclusion of the 'homogeneity' requirement with respect to the interpretation of EEA law (which is designed to ensure the EEA remains a homogenous trade zone). Both the EEA Agreement, and article 3 of the ESA/Court Agreement includes this rule, which provides that CJEU case law must be followed up to the point of signature of the EEA Agreement, and that 'due regard' be given to subsequent judgments. ${ }^{128}$ As Tobler argues, in practice the EFTA Court has gone beyond this in the interests of market integration, and has established a general presumption that identically worded provisions be interpreted in a similar way. ${ }^{129}$ There is also no reciprocal written obligation on the CJEU to be paying due regard to the relevant EFTA case law. Yet this paints too stark a picture. In practice, it is not a one-way street and the CJEU pays due account of EFTA case law. Over the years, there has been the evolution of a symbiotic 'judicial dialogue' marked by mutual respect. ${ }^{130}$

Be that as it may, the EU's support for a bespoke UK/EFTA docking model will in all probability be conditioned upon the homogeneity requirement (which was an issue with the Swiss (and the AMS States) negotiations). Writ large, the EU may also be cognisant of the fact that other Member States and EEA jurisdictions could pursue a similar strategy over the longer term, which could further distort from the EU and EEA's current homogeneity. ${ }^{131}$ On the UK side, in line with earlier observations on its Brexit policy, the homogeneity rule may also prove politically unpalatable, in addition to simply substituting the CJEU for another European Court. ${ }^{132}$

A further jurisdictional challenge could emerge when the current framework is directly applied to UK/EU financial governance disputes. The present EFTA model provides that, for

\footnotetext{
${ }^{126}$ Financial services aside, the EFTA/docking model would offer only a limited solution in that its mandate would not extend to, for instance justice and home affairs.

${ }^{127}$ C. Baudenbacher, After Brexit: Is the EEA an Option for the United Kingdom? 5; M. Clifton (n 105) 8.

${ }^{128}$ See also art 6 EEA Agreement.

${ }^{129}$ C. Tobler, 'One of Many Challenges after 'Brexit': The Institutional Framework of an Alternative Agreement - Lessons from Switzerland and Elsewhere?' (n 92) 582; see e.g. Case E-2/06 EFTA Surveillance Authority v Kingdom of Norway [2007] EFTA Court Report 164. Baudenbacher also talks of 'quasi direct effect' and 'quasi supremacy' in that the EEA-EFTA States have a Treaty obligation to behave as if EEA law had direct effect, and as a rule, the EFTA Court follows the CJEU case law but not always.

${ }^{130}$ C. Barnard (n 124) 154; C. Baudenbacher, 'The EFTA Court's Contribution to the Realisation of a Single Market' (2018) 18 European Business Law Review 671, 684. As Baudenbacher also identifies, the EFTA Court in many cases has had to tackle novel legal questions where these have not previously come before the CJEU.

${ }^{131}$ G. Wright (n 123).

132 J. Odermatt (n 119) 17.
} 
instance, in the situation where the Commission alleges that the UK has failed to fully implement the UK/EU agreement or is diverging from aspects of it, the ESA can decide to bring proceedings at the EFTA Court. The UK could then be declared compliant or noncompliant (and if declared non-compliant it would be legally obliged to implement the ruling, although compliance could not be forced and it would not face any financial penalty). In the situation where the UK wished to challenge EU action, however, (which could relate to the same scenario, such as the Commission threatening to revoke an equivalence assessment due to the UK's alleged regulatory divergence), then the current framework means that a Member State or an EU Institution would be in charge of bringing such a complaint to the CJEU under article 263 TFEU (again a non-privileged applicant such as a UK business could also attempt to bring a claim but this would be subject to satisfying the standing rules). Although as discussed above, it is conceivable that either another jurisdiction or the Parliament may be willing to instigate action, this could be overly optimistic. In any event, there is also the fact that this framework could end up with the EU marking its own homework. Nonetheless, perhaps this issue could be ameliorated by the institutional adjustments identified earlier, such as providing for the right of the UK to intervene, as well as the ability for it to appoint an ad hoc judge or Advocate General to the CJEU. ${ }^{133}$

Moreover, perhaps the judicial dialogue observable between the two courts over the years can offer some assistance in relation to jurisdictional issues. For instance, in the hypothetical situation where the ESA/EFTA Court assesses the UK to be compliant with its obligations, this legal ruling from an independent court should send a clear signal to the EU, of which due regard should be taken. ${ }^{134}$ In this regard there is an analogy in the 'clear salute' to the EFTA Court by the EU and Member States, which occurred in the Icesave dispute, (in something of a harbinger of the subsequent Brexit saga to come, this forum was selected after considerable consultation, including two Icelandic referendums where the voters rejected proposed solutions). ${ }^{135}$ The EFTA Court was used in Icesave to decide a financial governance dispute brought by the ESA (with the formal intervention by the Commission in support of it) between Iceland, and the UK and the Netherlands. ${ }^{136}$ It was claimed that since the Icelandic deposit guarantee fund in question was unable to compensate depositors in the UK and the Netherlands in relation to the insolvent bank Landsbanki, Iceland had to step in. The EFTA Court ultimately dismissed this action, an outcome that the EU, the UK and Netherlands all accepted. Accordingly (and whilst remaining mindful as to how far this precedent can transfer to the specific Brexit circumstances), given that the EFTA Court and its judgments have been recognised by the EU and the Member States, perhaps its ability to act as the independent legal forum for the UK/EU should not be underestimated. ${ }^{137}$

\footnotetext{
${ }^{133}$ A. Arnull (n 61).

${ }^{134}$ Baudenbacher argues that although the EU could in principle open legal proceedings, this has never occurred and that the EU could compromise itself to attack a well-reasoned judgment of the EFTA Court, (note as well that in the event of judicial conflict (EFTA/CJEU), for the EEA/EU States, in principle, there could be dispute settlement under article 111 EEA where parties can request a CJEU ruling, although as the EFTA side would have to accept this CJEU ruling, this is unlikely to ever happen), C. Baudenbacher, 'The EFTA Court's Contribution to the Realisation of a Single Market' (n 130134) 683.

${ }^{135}$ H. Fredriksen (n 106) 173.

${ }^{136}$ Case E-16/11 EFTA Surveillance Authority v Iceland [2013] EFTA Court Report 4.

${ }^{137}$ H. Fredriksen (n 106110) 173.
} 
Moving to the global level, the WTO is an international system with 164 member jurisdictions, and it has many roles, including negotiating and operating of global trade rules, as well as acting as a forum to settle trade disputes. Its dispute settlement system (that is drawn from international law) is a State-to-State system that could also play a role with respect to financial governance within a UK/EU future agreement.

The WTO system is also particularly of relevance given it is the default in the event that no EU/UK agreement emerges. Particularly with respect to financial governance access rights, the UK's access to the EU would then be governed by the WTO set-up and the related General Agreement in Trade and Services ('GATS')). In contrast to the EU's single market, the focus of the WTO is geared towards market access, whilst acknowledging that there can be much regulatory variance between its Members. Accordingly this structure would offer the UK basic access to the EU (such as to form a subsidiary in a Member State). This would only get the UK so far, however. For instance, the GATS 'most favoured nation' clause (that in principle provides that each WTO member extend preferential treatment to all other WTO members) does not apply to favourable treatment within systems of economic integration such as the EU's. ${ }^{138}$ Moreover, the WTO/GATS regime also permits governments to restrict cross-border financial services on the basis of prudential reasons, such as ensuring financial stability. Accordingly, relying purely on WTO terms would involve considerable limitations for the UK compared with its current access rights as a Member State.

\section{WTO Dispute Settlement}

Although there are significant drawbacks to the WTO terms as a model for future UK access rights, this does not mean the WTO's dispute system should be dismissed. As observed, this system will apply if there is no deal in place on the UK's departure. Next, depending on what future agreement is reached (if any); and taking account of the nature of the current Draft WA and Political Declaration discussed above, the future relationship could also be influenced by the WTO settlement mechanisms. This could include using the WTO settlement system as either 'the' or at least 'a' choice of dispute resolution system. The framework could also be tweaked to include the possibility of making a reference to the CJEU, although this could be of a voluntary nature only. ${ }^{139}$

It is notable that many States with free trade agreements in place (and which contain their own dispute resolution systems) choose to use the WTO set-up for dispute settlement, framing it as an issue concerning WTO obligations. ${ }^{140}$ This can be explained by a number of reasons including its informal system of precedent that bolsters certainty, the resources and support offered by the WTO Secretariat, and the respect the WTO commands, which generates legitimacy to the decisions. ${ }^{141}$ Indeed, its dispute settlement regime has been

\footnotetext{
${ }^{138}$ GATS article II; Annex on Financial Services; N. Moloney, 'Brexit, the EU and Its Investment Banker: Rethinking 'Equivalence' for the EU Capital Market' (n 12) 45.

${ }^{139}$ A. Tomás (n 93). For instance, the Canada-EU Trade Agreement ('CETA') essentially uses the WTO model and includes no role for the CJEU, S. Woolcock, What a CETA (or CETA+) Free Trade Agreement Would Mean (March 2018)

${ }^{140}$ Institute for Government, Dispute Resolution after Brexit (n 92) chapter 6.

${ }^{141}$ Ibid.
} 
described as the 'jewel in the crown' of the WTO. ${ }^{142}$ It is also significant to observe that the EU participates in the WTO, despite the impact of such decisions on the EU legal order. The indirect effect of WTO law, plus the flexibility inherent within the WTO's enforcement mechanisms (including that there is nothing that it can do to force compliance within the internal legal order) are key components in ensuring compatibility with the Treaties. ${ }^{143}$

\section{WTO Dispute Settlement Stages}

There are three particular stages to the WTO dispute system: first, consultations occur between the disputing States. If a mutually agreed solution cannot be found within a 60-day period, ${ }^{144}$ the dispute settlement body ('DSB') (a general committee of ambassadorial representatives of all the WTO members) will establish an arbitration Panel to consider the merits of the dispute and produce a Panel report. ${ }^{145}$ Following its due consideration, the final Panel report will be adopted, and in practice adoption is 'de facto automatic'. ${ }^{146}$ Conclusions are rarely overturned as this (now) requires 'negative' or 'reverse' consensus (this would be a consensus against adoption by all Members represented including the 'winning' party, meaning the losing side has little leverage). ${ }^{147}$

A decision can be appealed, although only on matters of law (international law is applied); and similarly such a ruling can only be rejected by negative consensus. ${ }^{148}$ Although, as observed in the article's introduction, the Appellate Body currently faces its own crisis due to the US blocking appointments and reappointments, a number of options have been put forward (including the use of binding arbitration rather than the Appellate Body) that could keep dispute settlement operational. Although it remains uncertain whether these types of technical fix will be sufficient, ${ }^{149}$ in principle such mechanisms could be capable of being applied in relation to future disputes between the UK and EU. ${ }^{150}$

In relation to enforcement; the State that loses must follow the recommendations of the report; if it fails to comply, then it has to enter into negotiations with the complaining State(s), and determine mutually acceptable compensation (such as tariff reductions). If this

${ }^{142}$ G. Messenger (n 11) 234.

${ }^{143}$ Case C-149/96 Portugal v Council ECLI:EU:C:1999:574; A. Tomás (n 93) 17-18; C. Hillion and R. Wessel, The European Union and International Dispute Settlement: Mapping Principles and Conditions (2017).

${ }^{144}$ WTO Understanding on Rules and Procedures Governing the Settlement of Disputes, art 4(7).

${ }^{145}$ Ibid esp. arts 6-8; 11-12. With respect to the recent disputes between the US and a number of its trading partners (many triggered by the US imposing tariffs on steel and aluminium plus the trade war with China), the WTO established Panels to examine measures and counter-measures imposed, WTO, Panels Established to Review US Steel and Aluminium Tariffs, Countermeasures on US Imports (November 2018).

${ }^{146}$ G. Messenger (n 11) 234.

${ }^{147}$ DSU, art 16. This rule also applies to the establishment of the Panel meaning there is an almost automatic decision to set up a Panel if the complainant is unwilling to join in the consensus.

148 Ibid art 17.

${ }^{149}$ C. Creamer (n 9).

${ }^{150}$ See e.g. N. Sen, The Appellate Body in Crisis (Linklaters) (2018); EU (and selected other WTO delegations), Proposals to Reform the WTO Appellate Body: WT/GC/W/752, WT/GC/W/753 (November 2018). 
is not agreed, the complainant can ask the DSB for permission to retaliate to encourage compliance (such as blocking imports; raising tariff duties). Accordingly, enforcement is flexible rather than a one-way street, and there is nothing that can force execution in domestic law. ${ }^{151}$

The system is generally regarded as a successful one; the negative consensus aspect facilitates decision-making and there are clear timeframes that avoid blockages. ${ }^{152}$ The WTO dispute settlement is also considered to be 'remarkably efficient' compared with other mechanisms (although delays are increasingly reported). ${ }^{153}$

\section{B WTO: UK/EU Future Financial Governance Disputes}

Particularly in relation to financial governance disputes, Lang makes a powerful argument that the WTO dispute settlement set-up could have the potential to play a valuable role. ${ }^{154}$ Historically, the WTO's dispute settlement organs have shown willing to step in where there has been a failure to follow good regulatory practice (such as in relation to a lack of objectivity, impartiality, or 'even-handedness'). ${ }^{155}$ In principle, the WTO could offer important oversight in relation to UK and EU actions that risk impacting on the competitive positions of foreign businesses within the respective markets. ${ }^{156}$

As Lang, and Alexander, argue, it is probable that the EU's equivalence rules could be subject to the GATS provisions. ${ }^{157}$ Although some uncertainty exists as to which GATS provisions may be utilised, Article VII, paragraphs 2, 3 and 5, and paragraph 3 of the Financial Services Annex are most likely to be applicable. With respect to financial governance, very broadly, these elements contain frameworks enabling a WTO Member to recognise the licences and certificates granted to service suppliers in foreign jurisdictions, and to recognise the prudential measures of another country. ${ }^{158}$ Further, although the GATS wording makes reference to the concept of 'recognition' rather than to equivalence (and a strict interpretation could suggest its inapplicability to the EU equivalence process), the preferable view is that the label recognition commonly refers to arrangements that also include aspects of equivalence and that functionally, the two terms are interchangeable. ${ }^{159}$

${ }^{151}$ DSU art 22; A. Tomás (n 93) section 2.1.

${ }^{152}$ Institute for Government, Dispute Resolution after Brexit (n 92) chapter 6.

${ }^{153}$ R. Malacrida and G. Marceau, 'The WTO Adjudicating Bodies' in Robert Howse (ed), The Legitimacy of International Trade Courts and Tribunals (CUP 2018) 57 (average times to receive final reports is within a year and a half). At the same time, there is no possibility of direct compensation for nonstate entities; and the UK's retaliation capacity will dwindle from no longer being a Member State, meaning it could make it tricky for it to effectively retaliate against countries such as the US and China.

${ }^{154}$ A. Lang (n 8). This section draws particularly on Lang's incisive analysis.

155 Ibid 157.

156 lbid 156.

${ }^{157}$ K. Alexander (n 7) 153.

${ }^{158}$ A. Lang (n 8) 203-205. Note that there is also a carve-out in the Financial Services Annex para 2 to enable governments to take measures (including restricting cross-border services) for prudential reasons including to ensure financial stability.

${ }^{159}$ T. Wei, 'The Equivalence Approach to Securities Regulation' (2007) 27 Nw J Int'I L \& Bus 255; A. Lang (n 8) 204-205. 
Concerning possible future challenges, these could be procedural or substantive. As discussed earlier in the article, procedural failings could include a refusal to grant equivalence, or an extensive delay in the equivalence process. In principle these types of complaints could constitute the basis of a WTO dispute. ${ }^{160}$ Lang identifies, however that this may not be entirely straightforward as the GATS regime (article VII and the Financial Services Annex) only applies where recognition has been granted and another state is wishing to be similarly recognised. It does not appear to apply where there is a refusal to grant recognition or there is a withdrawal of recognition in the scenario where no other State has been accorded similar recognition. This could generate difficulties for the UK if it wishes to make the latter type of challenge, particularly given its current levels of market access may surpass that of other non-EU States. ${ }^{161}$

In relation to potential substantive challenges, Lang argues that (subject to a number of caveats) the WTO dispute settlement system could be capable of scrutinising EU equivalence assessments for a lack of impartiality in comparison to other countries (using a relative standard). The GATS terms (both article VII and the Annex para 3) could enable such complaints, and although substantive disputes could be extremely delicate, the WTO system has previously been receptive to ensuring Members are impartial and not engaging in favouritism with respect to particular trading jurisdictions. ${ }^{162}$ Lang also suggests that the system could be capable of applying in relation to other categories of substantive challenge. This could include where there are suggestions that equivalence determinations are (for example) being delayed for other reasons, such as wider EU policy aims geared at attracting financial services entities to the EU. ${ }^{163}$ In addition to being mindful as to unrelated business and political elements entering into the equation, the WTO system could also be heedful of the EU adopting an overly legalistic stance to equivalence decisions and revocations, rather than determinations based on a more holistic, and outcomes-based approach. ${ }^{164}$

There are undoubtedly limitations to the WTO's dispute system. These include the GATS text, how far it can in fact extend to equivalence determinations, as well as more pragmatic factors such as the time that dispute resolution may take. Moreover, as observed above, given the UK's current political climate, transplanting the CJEU for the WTO may not sit well within parts of the UK. ${ }^{165}$ Yet, despite the political challenges, the potential for this

\footnotetext{
${ }^{160}$ See e.g. United States - Import Prohibition of Certain Shrimp and Shrimp Products WT/DS58/AB/R (adopted November 1998) (where the Appellate Body held that the rigidity of the US regulations in question and its absence of procedural standards of fairness and due process in its certification process with respect to foreign states' regulation led the Body to conclude the US measure was unjustifiable and arbitrary discrimination), RECIEL, United States - Import Prohibition of Certain Shrimp and Shrimp Products (1999); A. Lang (n 8) 208-209.

${ }^{161}$ A. Lang (n 8) 210-211.

162 Ibid 211-212.

${ }^{163}$ Ibid 211-213. Lang does note it is not certain that the GATS provisions offer a basis for this kind of review when measured by an absolute standard, but argues that there could be particular matters that merit greater scrutiny by the WTO dispute settlement system.

${ }^{164}$ Ibid.

${ }^{165} \mathrm{G}$. Messenger (n 11) 235.
} 
framework to play a significant role in future UK/EU financial governance dispute settlement should not be dismissed.

\section{A Conclusion: Which Way Forward?}

The Brexit saga continues unabated. This article addresses vital aspects with respect to the ongoing Brexit debate, particularly the topical questions generated by UK/EU financial governance and post-Brexit dispute settlement. The article has analysed the benefits and disadvantages of three possible systems via an original cross-model evaluation and it has explored the connected impediments that may be encountered in the pursuit of a postBrexit dispute settlement system. The article's overall analysis is also premised on the basis that functional interests should prevail in the Brexit negotiations, whilst remaining acutely mindful of the fact that Brexit itself is not a rational venture.

It is a herculean task to balance both parties' expectations and no option will ever be perfectly in keeping with either side's red lines. The various mechanisms explored in the article's preceding section illustrate that a number of different dispute settlement vehicles may be engaged for a future UK/EU partnership, depending particularly on whether or not a strong alliance can emerge. If a close UK/EU alliance can develop over the longer term, although the Swiss/EU draft framework (as currently utilised within the UK/EU draft documentation) could be engaged, the regional EFTA docking model could prove the preferable option for resolving post-Brexit disputes, albeit with the necessary adjustments built in.

With respect to the Swiss/UK scenarios, as observed in the preceding section, there are clear similarities. Both sets of negotiations are dragging on and neither the Swiss nor the UK want a long-term institutional framework where they have to relinquish formal sovereignty. ${ }^{166}$ In both cases, the EU also holds most of the cards, and does not wish to set any precedents or concessions that could be then claimed by the other. The EU's connecting of technical decisions on Swiss stock exchange equivalence with the progress of the EU/Swiss constitutional discussions is also notable. It offers a glimpse in relation to the approach concerning sensitive equivalence decisions, which could suggest that the granting or revoking of equivalence decisions can take on political elements, and which could also apply to the UK on its departure. ${ }^{167}$

Despite the similarities, it is important to be alive to the distinctions, however. Switzerland is engaging in a process of increased integration with the EU (albeit one that has hit various blockades); the UK is commencing an extended process of extraction and where any future new UK/EU agreement (from the UK side) is envisaged as not being conditional on the substantive harmonisation of laws with the EU or the referral of disagreements to the jurisdiction of the CJEU. Moreover, as identified, over the short-medium term, although the draft WA's mechanisms reflect a measured compromise, over the longer term, utilising an independent forum would avoid the risk of one party marking their own homework.

\footnotetext{
${ }^{166}$ R. Schwok, Brexit, Swiss "Model", Pros and Cons in Comparative Perspective (February 2018).

${ }^{167}$ M. Khan, 'Brussels Offers Swiss Exchanges Temporary Market Access' Financial Times (11 December 2018). As identified in section 3, in such instances, the UK or the Swiss could look to raise legal challenges to the effect that a particular decision was not being based on the relevant objective equivalence criteria, but in fact concerned unconnected motives.
} 
In the event of a future arrangement based on mutual respect and cooperation, the option of the UK docking at the EFTA Court has merit. This structure has its complexities, and there are practical hurdles in upscaling the framework to cater for a larger country such as the UK, but it offers a number of benefits. EFTA has no political integrationist agenda, it takes a common-sense approach, and it respects the UK's views on the CJEU. The EU has also previously indicated it is amenable to this option with the Swiss. At the same time the homogeneity principle may not wash well politically in the UK and there could be serious jurisdictional questions, most clearly highlighted where the UK wishes to challenge EU actions. Within the current model, such complaints would remain part of the CEJU's remit and this could equate to the EU policing itself. Whether or not the deep dialogue and respect that has emerged between the EFTA Court and the CJEU horizontally over the years can sufficiently temper such concerns remains an open question. The Icesave precedent may augur well although it can be questioned how much comfort this precedent can offer to the UK in the unique circumstances of Brexit.

If the progress of the future UK/EU negotiations hit further blockades, however, a looser affiliation that draws on the WTO model would appear prudent, indeed this may be the only realistic basis on which to tailor future dispute settlement mechanisms. ${ }^{168}$ Although the ethos of the WTO set-up is extremely different to that of EU law, of itself this makes it a topic of much interest in the UK. Moreover as the preceding section illustrates, despite the limits to the WTO and its dispute resolution framework, it may be able to provide impartial oversight over the UK and EU in the field of financial governance. This is especially so with respect to the UK and EU's equivalence process, including acting as a type of watchdog in relation to any extraneous elements filtering into the decision-making. Given such elements have arisen with Switzerland, it is not fanciful to envisage this could take also place with the UK, even if not couched in such terms. Nevertheless, for the WTO system to have any traction, astute political effort will also be required with respect to a 'new' international court having the jurisdiction to rule on aspects of UK policy.

${ }^{168}$ A. Tomás (n 93) 44. 